\title{
What is the importance of open habitat in a predominantly closed forest area to the dung beetle (Coleoptera, Scarabaeinae) assemblage?
}

\author{
Fábio C. Costa ${ }^{1}$, Karen K. T. Pessoa ${ }^{1}$, Carolina N. Liberal ${ }^{2}$, Bruno K. C. Filgueiras ${ }^{1}$, \\ Renato P. Salomão ${ }^{1} \&$ Luciana Iannuzzi ${ }^{1,3}$
}

\footnotetext{
${ }^{1}$ Departamento de Zoologia, Universidade Federal de Pernambuco, 50670-901 Recife-PE, Brazil.

2 Departamento de Sistemática e Ecologia, Universidade Federal da Paraíba, 58051-900 João Pessoa-PB, Brazil.

${ }^{3}$ Corresponding author: lucianaiannuzzi@gmail.com
}

\begin{abstract}
What is the importance of open habitat in a predominantly closed forest to the dung beetle assemblage? The Atlantic Forest in Brazil is one of the most highly disturbed ecosystems and is mainly represented by fragmented areas. However, in places where human disturbances have ceased, certain areas are showing a natural regeneration pattern. The aim of the present study was to determine how the dung beetle assemblage responds to distinct habitat structures in a fragment of Atlantic Forest. For such, open and closed forest areas were sampled in a fragment of the Atlantic Forest in the northeastern region of Brazil. Pitfall traps baited with excrement and carrion were used to collect the beetles. A total of 7,267 individuals belonging to 35 species were captured. Canthon chalybaeus and C. mutabilis were restricted to open areas. Nearly $90 \%$ of the individuals of $C$. aff. simulans and Deltochilum aff. irroratum were identified in these areas. A higher percentage $(>50 \%)$ of Canthon staigi, Dichotomius aff. depressicolis and D. aff. sericeus occurred in closed areas. Abundance differed between areas, with higher values in closed areas. Richness was not influenced by the habitat structure. NMDS ordination exhibited the segregation of areas and ANOSIM confirmed that this variable explained the assemblage of dung beetle species. The findings of the present study validate that open areas are associated to more restrictive conditions, limiting a higher abundance of dung beetle. Although situated near preserved fragments, the studied open areas increase the heterogeneity of the general landscape.
\end{abstract}

KEYWORDS. CIMNC; distribution patterns; Insecta; spatial heterogeneity.

The agriculture cycles in northeastern Brazil, which started in the $16^{\text {th }}$ century with sugarcane plantations, have altered the natural habitats of the Atlantic Forest, which currently has approximately only $7.8 \%$ of its original area (Tabarelli et al. 2006). This forest offers a broad diversity of environments with particular climatic and structural characteristics, supporting one of the most distinctive biogeographical units in the entire Neotropical region, the Pernambuco Centre (Prance 1987). Despite its ecological importance, fragments of the Atlantic Forest have a mean size of 10 ha, which is insufficient for the establishment of k-strategist organisms (Ranta et al. 1998). Besides the small size, the forest remnants have also been highly altered and are usually surrounded by the sugarcane matrix. However, regeneration strategies directed at altered sites and the conservation of undisturbed forests has allowed changes in this scenario (Ranta et al. 1998). In abandoned areas of sugarcane, for example, regeneration has occurred and different stages of plant succession and structural complexity are currently found (Ranta et al. 1998; Asfora \& Pontes 2009). Regeneration activities as the establishment of ecological corridors, conservation units and reforestation techniques can contribute toward the recovery and/or maintenance of the Atlantic Forest and floristic and faunal communities (Henein \& Merrian 1990; SCBD 2008).

Due to the high degree of deforestation of the remnants surrounded by modified habitats, the edge effect is very strong in comparison to preserved sites (Santos et al. 2010). Furthermore, altered environments often have a high number of clearings due to logging activities (Stone \& Lefebvre 1998). Consequently, there is a tendency toward a simplification of the biota, resulting from the reduction in area and the homogenization of habitats (Murcia 1995; Rodrigues 1998; Bierregaard Jr. et al. 2001). On the other hand, natural open habitats show a tendency to be occupied by specialized taxa that requires conditions of less humidity and higher sunlight and temperature, characteristics that are common on these environments (Costa et al. 2009; Gossner 2009).

Habitat loss has a direct effect on biological diversity and species that are more resistant to environmental alterations exhibit faster recovery rates (Santos et al. 2010). Such is the case with some species of dung beetles (Pineda et al. 2005; Davis et al. 2012). Although they feed essentially on decaying matter, these insects are not particularly specialized with regard to the type of resource (Halffter \& Matthews 1966; Gill 1991; Quintero \& Roslin 2005; Halffter \& Halffter 2009). Dung beetles are also excellent bioindicators, as their distribution is directly related to the composition of the flora and fauna (Nichols et al. 2007, 2009; Hernández \& Vaz-de-Mello 2009).

Dung beetles respond differently to the variety of matrices in forest fragments and vegetal succession gradients, exhibiting variation with regard to abundance and species composition (Nichols et al. 2007; Noriega et al. 2007; Neves 
et al. 2010). The presence of medium-size to large vertebrates also influences dung beetle diversity, as these insects depend on such animals as resource providers (Andresen \& Laurance 2007; Nichols et al. 2009). In the Neotropics, the greatest diversity of dung beetles occurs in closed forest areas, mainly due to the higher availability of food sources and nesting conditions (Hanski \& Cambefort 1991).

The aims of the present study were to describe how the dung beetle assemblage is distributed among different habitats in a remnant of the northeastern Brazilian Atlantic Forest. More specifically, we tested the hypothesis that despite of the disturbance history, the recent secondary regeneration is already sufficient for a distinction in dung beetle assemblage between closed and open habitats.

\section{MATERIAL AND METHODS}

Study site. The study was conducted at Campo de Instrução Marechal Newton Cavalcanti (CIMNC), located in the state of Pernambuco, northeastern Brazil (07 $50^{\circ} \mathrm{S}$ and $\left.35^{\circ} 06^{\prime} \mathrm{W}\right)$. The CIMNC is a military unit established in 1944 through the expropriation of ten sugarcane plantations for the training of military troops. The camp still serves for training and military exercises. The CIMNC is located among the cities of Abreu e Lima, Araçoiaba, Igarassu, Paulista, Paudalho and Tracunhaém, with 7,324 ha covering both forested and urbanized areas. The mean annual minimum and maximum temperature is $20.4^{\circ} \mathrm{C}$ and $30.4^{\circ} \mathrm{C}$, respectively, with a mean annual precipitation of $1,175 \mathrm{~mm}$. The region has a rainy tropical climate with a dry summer, with the rainfall concentrated between February and October (LAMEPE 2010). The soil is composed of latosols and podzolics on the top of plateaus and residual tops; podzolics with fragipan, plinthic podzolics and podzols on the small depressions of the Tabuleiro; concretionary podzolics in dry areas and on cliffs; and gleysol and alluvial soils in meadow areas (Beltrão et al. 2005).

The CIMNC fragment is considered one of the largest continuous patches of the Atlantic Forest north of the São Francisco River, with lowland dense rainforest (IBGE 1992). The area was previously used for sugarcane cultivation. The cessation of monoculture activities following the use by the Brazilian Army over 60 years ago has led to its current state of secondary regeneration succession (Rego et al. 2004).

Data collection. Beetles were collected from 12 areas of the CIMNC at sites spaced at least 1,000 m apart - six open areas and six closed areas. Open areas were characterized by sparse plant cover and no canopy and essentially composed of grasses. Closed areas had canopy coverage ranging from 7 to $10 \mathrm{~m}$ and more closed plant coverage than the open areas. Both habitat types have undergone succession for the same amount of time after cessation of agricultural activities on them and were at least $100 \mathrm{~m}$ from the edge of the forest (Lucena 2009). Sampling was performed monthly from January to May 2010, using pitfall traps baited (see Filgueiras et al. 2011) with human excrement $(30 \mathrm{~g})$ and bovine carrion spleen $(30 \mathrm{~g})$. Each sampling unit was established for four traps ( 2 with excrement and 2 with carrion). The traps were distributed in two sets spaced $20 \mathrm{~m}$ apart, each with two types of bait ( $3 \mathrm{~m}$ between baits).

Statistical analysis. Abundance of species that predominated in a type of habitat ( $>50 \%$ of individuals) was compared between the two habitats (open and closed) using Generalized Linear Models with a Poisson error distribution. Whenever data exhibited statistical difference, their normality was checked through the Shapiro-Wilk test (W-test).

One-Factor ANOVA was used to compare the abundance and richness of dung beetles between the types of sites (open and closed). In an attempt to avoid the non normality and heteroscedasticity of variances, data of abundance were square-root transformed. These analyses were carried out with the aid of the STATISTICA 7.0 program.

Non-metric multidimensional scaling (NMDS) was used to determine overall differences in species abundance and composition between open and closed sites. Ordination was determined for abundance and composition using the BrayCurtis index. Analysis of similarities (ANOSIM) was used to determine differences in species abundance and composition between sites. NMDS and ANOSIM analyses were carried out using the Primer 6 program.

The number of species present at sites was estimated using the non-parametric estimator Jack 1. Rarefaction curves for closed and open habitats were constructed using individual-based rarefaction.

\section{RESULTS}

A total of 7,267 beetles distributed among 13 genera and 35 species were captured. Dichotomius aff. sericeus and Canthon staigi were the most abundant species, corresponding to $38.7 \%$ and $26.4 \%$ of the overall sample, respectively. Among the most abundant species (more than $1 \%$ of total abundance), all of them were attracted to both baits. Pseudocanthon and Sylvicanthon species were exclusively attracted by excrement. Regarding abundance, carrion attracted the majority of individuals (58\%) (Table I).

Among the most abundant species, the majority had a preference for some type of habitat. Nearly $90 \%$ of the individuals of Canthon aff. simulans and Deltochilum aff. irroratum were captured in open areas. Significant differences were found in abundance of the Canthon aff. simulans ( $\mathrm{F}=95.4 \mathrm{df}=1, \mathrm{p}<$ $0.0001)$ and $D$. aff. irroratum $(\mathrm{F}=5.43, \mathrm{df}=1, \mathrm{p}=0.019)$ between sites, although for both of them the data did not exhibit normal distribution $(C$. aff. simulans: $\mathrm{W}=0.704, \mathrm{p}=$ 0.0068 ; D.aff. irroratum: $\mathrm{W}=0.714, \mathrm{p}=0.008$ ) showing that they had a grouped distribution. A higher percentage (>50\%) of C. staigi, Dichotomius aff. depressicolis and Dichotomius aff. sericeus occurred in the closed areas of the fragment (Table I). Similarly, significant differences were found in abundance of C. staigi $(\mathrm{F}=247.18, \mathrm{df}=1, \mathrm{p}=0.001), D$. aff. depressicolis $(\mathrm{F}=17.29, \mathrm{df}=1, \mathrm{p}=0.001)$ and $D$. aff. sericeus $(\mathrm{F}=1104.34$, $\mathrm{df}=1, \mathrm{p}=0.001)$ between open and closed areas. On the other 
Table I. Species of dung beetles, and respective abundance according to habitat and bait type, of an Atlantic Forest fragment (CIMNC), in Abreu Lima, Pernambuco, Brazil.

\begin{tabular}{|c|c|c|c|c|}
\hline \multirow{3}{*}{ Taxa } & \multicolumn{4}{|c|}{ Habitat and bait type } \\
\hline & \multicolumn{2}{|c|}{ Open } & \multicolumn{2}{|c|}{ Closed } \\
\hline & Carrion & Dung & Carrion & Dung \\
\hline Ateuchus sp. 1 & 0 & 10 & 1 & 20 \\
\hline Ateuchus sp. 2 & 6 & 0 & 24 & 1 \\
\hline Canthidium sp. 1 & 7 & 20 & 1 & 60 \\
\hline Canthidium sp. 2 & 1 & 3 & 1 & 0 \\
\hline Canthidium sp. 3 & 3 & 1 & 1 & 0 \\
\hline Canthidium sp. 4 & 1 & 0 & 1 & 0 \\
\hline Canthidium sp. 5 & 1 & 0 & 1 & 0 \\
\hline Canthon aff. scrutator Balthasar, 1939 & 17 & 2 & 8 & 1 \\
\hline Canthon chalybaeus Blanchard, 1843 & 62 & 14 & 0 & 0 \\
\hline Canthon mutabilis Harold, 1867 & 426 & 71 & 0 & 0 \\
\hline Canthon nigripennis Lansberge, 1874 & 20 & 17 & 9 & 20 \\
\hline Canthon histrio LaPeletier and Serville, 1828 & 2 & 1 & 0 & 1 \\
\hline Canthon aff. simulans Martinez, 1950 & 66 & 140 & 0 & 33 \\
\hline Canthon staigi (Pereira, 1953) & 176 & 309 & 770 & 667 \\
\hline Canthonella silphoides (Harold, 1867) & 2 & 0 & 5 & 3 \\
\hline Coprophanaeus aff. ensifer (Germar, 1824) & 4 & 0 & 15 & 1 \\
\hline Coprophanaeus acrisius (Macleay, 1819) & 1 & 0 & 0 & 0 \\
\hline Coprophanaeus cyanescens (Olsoufieff, 1924) & 3 & 0 & 0 & 0 \\
\hline Coprophanaeus punctatus (Olsoufieff, 1924) & 2 & 0 & 11 & 1 \\
\hline Coprophaneus dardanus (MacLeay, 1819) & 1 & 1 & 8 & 1 \\
\hline Deltochilum pseudocairus Balthasar,1939 & 0 & 0 & 1 & 0 \\
\hline Deltochilum aff. irroratum (Laporte, 1840) & 72 & 12 & 8 & 0 \\
\hline Deltochilum sp. & 128 & 17 & 371 & 66 \\
\hline Dichotomius sp. & 0 & 0 & 0 & 1 \\
\hline Dichotomius aff. bicuspis Germar, 1824 & 1 & 0 & 0 & 0 \\
\hline Dichotomius aff. depressicolis (Harold, 1867) & 1 & 0 & 66 & 0 \\
\hline Dichotomius aff. sericeus (Harold, 1867) & 217 & 186 & 1,270 & 1,140 \\
\hline Dichotomius nisus (Olivier, 1789) & 1 & 0 & 0 & 0 \\
\hline Eurysternus caribaeus (Herbst, 1789) & 42 & 1 & 35 & 1 \\
\hline Eurysternus aff. hirtellus Dalman, 1824 & 201 & 97 & 132 & 115 \\
\hline Onthophagus ranunculus Arrow, 1913 & 2 & 0 & 0 & 0 \\
\hline Pseudocanthon aff. xanthurus (Blanchard, 1843) & 0 & 6 & 0 & 0 \\
\hline Sylvicanthon sp. & 0 & 1 & 0 & 0 \\
\hline Trichillum externepunctatum Borre, 1886 & 16 & 0 & 0 & 0 \\
\hline Uroxys sp. & 0 & 0 & 0 & 2 \\
\hline Total abundance & 1,482 & 909 & 2,743 & 2,134 \\
\hline Total richness & 29 & 19 & 21 & 18 \\
\hline
\end{tabular}

hand, $C$. staigi $(\mathrm{W}=0.87, \mathrm{p}=0.227)$ and $D$. aff. sericeus $(\mathrm{W}=$ $0.803, \mathrm{p}=0.062$ ) had normal distribution, but $D$. aff. depressicolis $(\mathrm{W}=0.532, \mathrm{p}<0.0001)$ exhibited an aggregate distribution.

In the comparison of CIMNC areas, a significant difference was found in dung beetle abundance $\left(\mathrm{F}_{1 ; 58}=20.753\right.$, $\mathrm{p}$ $=0.00003)$ (Fig. 1), with greater abundance occurring in closed areas $(n=4,877)$ in comparison to open areas $(n=$ 2,390). The richness values were not different between areas $\left(\mathrm{F}_{1 ; 58}=1.2266, \mathrm{p}=0.27265\right)$ although more species were captured in open habitats than closed habitats (Fig. 2). In this way, open habitats exhibited the highest value for Simpson's diversity index $(1 / \mathrm{D}=6.673)$. Estimation of total species number for both open and closed habitats indicated a high level of completeness (see Table II).

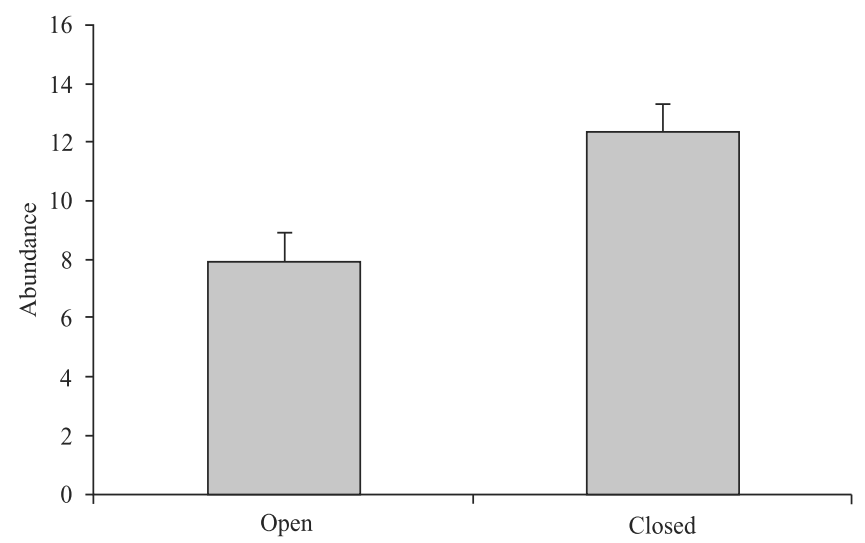

Fig. 1. Average and standard error (bar) of abundance of dung beetle community in open and closed habitats of an Atlantic Forest fragment (CIMNC), in Abreu e Lima, Pernambuco, Brazil.

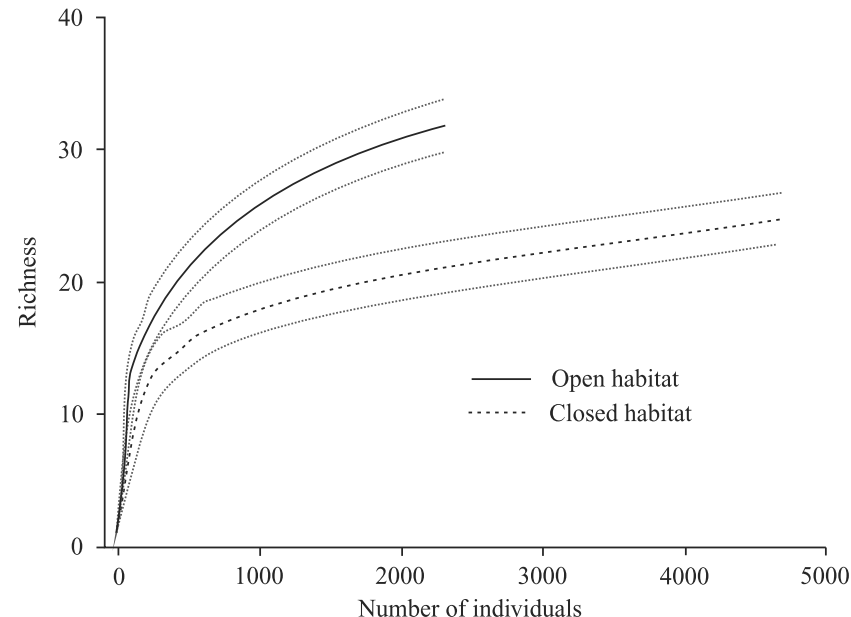

Fig. 2. Individual-based rarefaction curves for dung beetles in open and closed habitats of an Atlantic Forest fragment (CIMNC), in Abreu e Lima, Pernambuco, Brazil. Dotted-lines are 95\% confidence intervals (CI).

Table II. Abundance, species richness, estimated species richness and diversity index for dung beetles in open and closed habitats of an Atlantic Forest fragment (CIMNC), in Abreu e Lima, Pernambuco, Brazil.

\begin{tabular}{lccccc}
\hline & Abundance Richness & $\begin{array}{c}\text { Estimated richness } \\
(\text { Jack 1) }\end{array}$ & Completeness* & $\begin{array}{c}\text { Simpson } \\
(1-\lambda)\end{array}$ \\
\hline Open habitat & 2391 & 31 & 37.67 & 82.39 & 6.673 \\
Closed habitat & 4873 & 25 & 29.54 & 84.63 & 2.856 \\
\hline
\end{tabular}

* Percentage of Jack 1 estimate in relation to observed richness.

The NMDS provided a good representation of the similarity matrices among the dung beetles in the areas sampled (stress $=0.06-$ species composition; stress $=0.01-$ abundance) (Fig. 3). The ordination exhibited the grouping of areas and ANOSIM confirmed that the variable "area" explained the species composition (global $\mathrm{R}=0.279$, $\mathrm{p}=0.009$, number of permutations $=999)$ and abundance (global $\mathrm{R}=0.433, \mathrm{p}=0.002$, number of permutations $=$ 999).

Revista Brasileira de Entomologia 57(3): 329-334, September 2013 


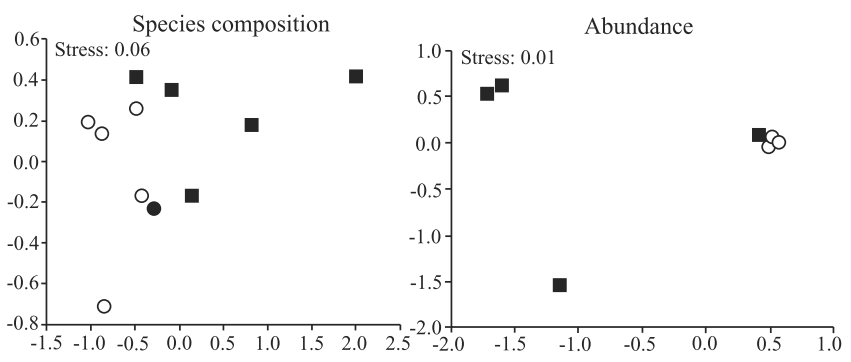

Fig. 3. NMDS ordination of dung beetle community (major groups) in open and closed habitats of an Atlantic Forest fragment (CIMNC), in Abreu e Lima, Pernambuco, Brazil. (ם) Open habitat, $(\bigcirc)$ closed habitat.

\section{DISCUSSION}

The present study investigated the structural relationship between open and close habitats of a fragment of the Atlantic Forest and the dung beetle assemblage. The diversity of this group was similar to that reported in other studies carried out in northeastern Brazil (Costa et al. 2009; Silva et al. 2010). Dichotomius aff. sericeus and C. staigi were the most abundant species in the present study, distributed mainly in closed habitats. Members of the complex D. aff. sericeus and C. staigi have been shown to be predominant components at Atlantic Forest sites in northeastern Brazil, mostly associated with closed habitats (Endres et al. 2007; Costa et al. 2009; Silva et al. 2010; Filgueiras et al.2011). The type of environment also played an important role in the distribution of other species. For instance, Canthon mutabilis and C. chalybaeus were restricted to open areas. Canthon mutabilis occurs throughout most of South America, always associated with dry savanna and open moist areas (Solís \& Kohlmann 2002; Silva 2011). In Brazil, C. chalybaeus is more abundant on the edge of forests and in pastures used for cattle grazing than within forests (Lopes et al. 2011). Thus, the exposed conditions of open areas seem to benefit these species, which, in turn, constitute an indicator of this condition.

The established mosaic of the CIMNC fragment exerts an influence on the conservation of dung beetles. Most significantly, abundance was higher in areas where the plant structure was denser. In Neotropical rainforests, closed forests with a high degree of conservation constitute the most favorable condition for the establishment of assemblages of this beetle group (Howden \& Nealis 1975; Gill 1991; Spector \& Azayama 2003; Kohlmann et al. 2007). In these wetter habitats the availability of resources remains viable for longer periods (Halffter \& Matthews 1966; Halffter 1991). On the other hand, some species of the dung beetle assemblage exhibited greater affinity to open areas, with higher abundance in these areas, in addition to those species that were found only in this type of habitat. This may explain the higher value of diversity index for open areas. The species composition of dung beetles over distinct areas may be explained by evolutionary traits. Species that occupy open areas show a tendency to use the resources quickly due to faster desiccation, avoiding the abiotic factors that limit the resource utilization (Larsen et al. 2006; Almeida \& Louzada 2009). This proves the importance of open areas as much as closed areas.

On the other hand, the type of habitat (open or closed) did not exert an influence on the richness of dung beetle species. This finding does not lend support to the hypothesis put forth. In comparison to closed areas, open areas commonly display a tendency toward an increase in the number of species over time as the forest naturally regenerates (Quintero \& Roslin 2005; Quintero \& Halffter 2009). However, some disturbed environments in the regeneration process do not exhibit differences in the dung beetle communities between open and closed habitats (Silva et al. 2010). The distinct responses to regeneration in terms of dung beetle richness are related to the different kinds of disturbance, i.e., fire or logging (Hobbs \& Huenneke 1992). In the fragment studied herein, despite extensive logging for decades, the area has been in a process of natural regeneration for over 60 years (Rego et al. 2004). In the present study it was observed a homogenization in both areas with regard to richness. Despite the lower abundance in comparison to closed forest areas, species from an earlier stage of regeneration can cross open areas, even if they have a decreased presence when compared with the closed forest (Nichols et al. 2007). Another factor could be the narrow forest contour of some open areas in the CIMNC, enabling the colonization of species that require some specific conditions (Davis et al. 2002).

Despite the low global R-values in both analysis (presence/absence and abundance), species composition was distinct between the two habitats. However, abundance nested most of the studied sites, except for three open sites that were distinct from the others in both analyses. In these sites, sandy soil is predominant and, associated to the distinct plant cover, composed mainly by grasses, may have contributed to the distinct distribution of dung beetles. Sandy areas make tunneling, reproduction and larval growth more difficult, and constitutes a restrictive habitat for the occurrence of some dung beetle species (Fincher 1973). Likewise, one closed site was separated from the others; it is located in the most preserved portion of the forest remnant, having suffered little, if any, deforestation (Davis et al. 2002).

The results of the present study suggest that distinct habitats act complementarily for the structure of the dung beetle assemblage in the Atlantic Forest. One may therefore conclude that the conservation of forest remnants contributes to regeneration and the consequent diversification and maintenance of dung beetle assemblage. These insects are effective bioindicators, exhibiting a well-established structure in preserved areas. This same pattern can be extrapolated to other components of biodiversity.

\section{ACKNOWLEDGEMENTS}

We thank Richard Boyke for the translation of the text and Fernando Zagury Vaz-de-Mello, Federal University of Mato Grosso, Brazil, for the taxonomic identifications. We 
are grateful to Coordenação de Aperfeiçoamento de Pessoal de Nivel Superior and Programa de Pós Graduação em Biologia Animal for support to the graduate students F. C. Costa, R. P. Salomão and B. K. C. Filgueiras. We thank the Brazilian Military Service for authorizing our fieldwork at the Campo de Instrução Marechal Newton Cavalcanti.

\section{REFERENCES}

Almeida, S.S.P. \& Louzada, J.N.C. 2009. Estrutura da comunidade de Scarabaeinae (Scarabaeidae: Coleoptera) em fitofisionomias do Cerrado e sua importância para a conservação. Neotropical Entomology 38: $32-43$.

Andresen, E. \& Laurance, S.G.W. 2007. Possible indirect effects of mammal hunting on dung beetle assemblages in Panama. Biotropica 39: 141-146.

Asfora, P.H. \& Pontes, A.R.M. 2009. The small mammals of the highly impacted North-eastern Atlantic Forest of Brazil, Pernambuco Endemism Center. Biota Neotropica 9: 31-35.

Beltrão, A.B., Mascarenhas, J.C., Miranda, J.L.F., Souza Jr., L.C., Galvão, M.J.T.G. \& Pereira, S.N. 2005. Diagnóstico do município de São José da Coroa Grande. Projeto Cadastro de Fontes de Abastecimento por Água Subterrânea do Estado de Pernambuco. Recife, Ministério de Minas e Energia, PRODEEM/CPRM, 10 p.

Bierregaard Jr., R., Gascon, C., Lovejoy, T.E. \& Mesquita, R. 2001. Lessons from Amazonia: the ecology and conservation of a fragmented forest. New Haven, Yale University Press, 496 p.

Costa, C.M. Q., Silva, F.A.B., Farias, A.I. \& Moura, R.C. 2009. Diversidade de Scarabaeinae (Coleoptera, Scarabaeidae) coletados com armadilha de interceptação de vôo no Refúgio Ecológico Charles Darwin, IgarassuPE, Brasil. Revista Brasileira Entomologia 53: 88-94.

Davis, A.L.V., Van Aarde, R.J., Scholtz, C.H. \& Delport, J.H. 2002. Increasing representation of localized dung beetles across a chronosequence of regenerating vegetation and natural dune forest in South Africa. Global Ecology \& Biogeography 11: 191-209.

Davis, A.L.V., Scholtz, C.H., Swemmer, A.S. 2012. Effects of land usage on dung beetle assemblage structure: Kruger National Park versus adjacent farmland in South Africa. Journal of Insect Conservation 16: $399-411$.

Endres, A.A., Creão-Duarte, A.J. \& Hernandéz, M.I.M. 2007. Diversidade de Scarabaeidae s. str. (Coleoptera) da Reserva Biológica Guaribas, Mamanguape, Paraíba, Brasil: uma comparação entre Mata Atlântica e Tabuleiro Nordestino. Revista Brasileira de Entomologia 51: 6771.

Filgueiras, B.K.C., Iannuzzi, L. \& Leal, I.R. 2011. Habitat fragmentation alters the structure of dung beetle communities in the Atlantic Forest. Biological Conservation 144: 362-369.

Fincher, G.T. 1973. Nidification and reproduction of Phanaeus spp. in three textural classes of soil (Coleoptera: Scarabaeidae). Coleopterists Bulletin 27: 33-37.

Gill, B.D. 1991. Dung beetles in Tropical American forests, p. 211-229. In: I. Hanski \& Cambefort, Y. (eds.). Dung Beetle Ecology. Princeton, Princeton University Press, $481 \mathrm{p}$.

Gossner, M.M. 2009. Light intensity affects spatial distribution of Heteroptera in deciduous forests. European Journal of Entomology 106: $241-252$

Halffter, G. 1991. Historical and ecological factors determining the geographical distribution of beetles (Coleoptera: Scarabaeidae: Scarabaeinae). Folia Entomológica Mexicana 82: 195-238.

Halffter, G. \& Matthews, E.G. 1966. The natural history of dung beetles of the subfamily Scarabaeinae (Coleoptera: Scarabaeidae). Folia Entomológica Mexicana 12-14: 1-312.

Halffter, G. \& Halffter, V. 2009. Why and where coprophagous beetles (Coleoptera: Scarabaeinae) eat seeds, fruits or vegetable detritus. Boletín de la Sociedad Entomólogica Aragonesa 45: 1-22.
Hanski, I. \& Cambefort, Y. 1991. Competition in dung beetles, p. 305329. In: Hanski, I. \& Cambefort, Y. (eds.). Dung Beetle Ecology. Princeton, Princeton University Press, $481 \mathrm{p}$.

Henein, K. \& Merriam, G. 1990. The elements of connectivity where corridors quality is variable. Landscape Ecology 4: 157-170.

Hernández, M.I.M. \& Vaz-de-Mello, F.Z. 2009. Seasonal and spatial species richness variation of dung beetle (Coleoptera, Scarabaeidae s. str.) in the Atlantic Forest of southeastern Brazil. Revista Brasileira de Entomologia 53: 607-613.

Hobbs, R.J. \& Huenneke, L.F. 1992. Disturbance, diversity and invasion: Implications for conservation. Conservation Biology 6: 324-337.

Howden, H.F. \& Nealis, V.G. 1975. Effects of clearing in a tropical rain forest on the composition of the coprophagous scarab beetle fauna (Coleoptera). Biotropica 7: 77-83.

IBGE (Fundação Instituto Brasileiro de Geografia e Estatística). 1992. Atlas Nacional do Brasil. Rio de Janeiro, IBGE, 93 p.

Kohlmann, B., Solís, A., Elle, O., Soto X. \& Russo, R. 2007. Biodiversity, conservation and hospot atlas of Costa Rica: a dung beetle perspective (Coleoptera: Scarabaeidae: Scarabaeinae). Zootaxa 1457: 1-34.

LAMEPE . 2010. Database. Available from: http://www.itep.br/index.php/ links-hidromet/monitoramento/monitoramento-pluviometrico (acessed 8 October 2010).

Larsen, T.H., Lopera, A. \& Forsyth, A. 2006. Extreme trophic and habitat specialization by Peruvian dung beetles (Coleoptera: Scarabaeidae: Scarabaeinae). The Coleopterists Bulletin 60: 315-324.

Lopes, J., Korasaki, V., Catelli, L.L., Marçal, V.V.M. \& Nunes, M.P.B.P. 2011. A comparison of dung beetle assemblage structure (Coleoptera: Scarabaeidae: Scarabaeinae) between an Atlantic forest fragment and adjacent abandoned pasture in Paraná, Brazil. Zoologia 28: 72-79.

Lucena, M.F.A. 2009. Flora da Mata do CIMNC, Pernambuco, Brasil. Recife, Apoio a Criação de Unidades de Conservação na Floresta Atlântica de Pernambuco, 18 p.

Murcia, C. 1995. Edge effects in fragmented forests: implications for conservation. Tree 10: $58-62$.

Neves, F.S., Oliveira, V.H.F., Espírito-Santo, M.M., Vaz-de-Mello, F.Z., Louzada, J., Sanchez-Azofeita, A. \& Fernandes, G.W. 2010. Successional and seasonal changes in a community of dung beetles (Coleoptera: Scarabaeinae) in a Brazilian tropical dry forest. Natureza \& Conservação 8: 160-164.

Nichols, E., Larsen, T., Spector, S., Davis, A.L., Escobar, F., Favila, M., Vulinec, K. \& The Scarabaeinae Research Network. 2007. Global dung beetle response to tropical forest modiûcation and fragmentation: A quantitative literature review and meta-analysis. Biological Conservation 137: 1-19.

Nichols, E., Gardner, T.A., Peres, C.A., Spector, S. \& The Scarabaeinae Research Network. 2009. Co-declining mammals and dung beetles: an impending ecological cascade. Oikos 118: 481-487.

Noriega, J.A., Realpe, E. \& González, G.F. 2007. Diversidad de escarabajos coprófagos (Coleoptera: Scarabaeidae) en un bosque de galería con tres estadios de alteración. Univsersitas Scientiarum 12: 51-63.

Pineda, E., Moreno, C., Escobar, F. \& Halffter, G. 2005. Frog, bat and dung beetle diversity in the cloud forest and coffee agroecosystems of Veracruz, Mexico. Conservation Biology 19: 400-410.

Prance, G.T. 1987. Biogeography of neotropical plants, p. 174-196. In: Whitmore, T.C. \& Prance G.T. (eds.). Biogeography and Quaternary history in tropical America. Oxford, Oxford University Press, $224 \mathrm{p}$.

Quintero, I. \& Roslin, T. 2005. Rapid recovery of dung beetle communities following habitat fragmentation in central Amazonia. Ecology 86: 3303-3311.

Quintero, I. \& Halffter, G. 2009. Temporal changes in a community of dung beetles (Insecta: Coleoptera: Scarabaeinae) resulting from the modification and fragmentation of tropical rain forest. Acta Zoológica Mexicana 25: 625-649.

Ranta, P., Blom, T., Niemelä, J., Joensuu, E. \& Siitonen, M. 1998. The fragmented Atlantic rain forest of Brazil: size, shape and distribution of forest fragments. Biodiversisty \& Conservation 7: 385-403.

Rego, B.N., Maragon, L.C. \& Feliciano, A.P. 2004. Florística e estrutura 
horizontal de um fragmento de floresta Atlântica no município de Pau D'alho-PE. IV Jornada de Ensino, Pesquisa e Extensão da UFRPE: $1-2$.

Rodrigues, E. 1998. Efeito de bordas em fragmentos de floresta. Cadernos da Biodiversidade 1: 1-6.

Santos, B.A., Arroyo-Rodríguez, V., Moreno, C.E. \& Tabarelli, M. 2010. Edge-related loss of tree phylogenetic diversity in the severely fragmented Brazilian Atlantic Forest. PLoS ONE 5: e12625. doi:10.1371/journal.pone.0012625.

SCBD (Secretariat of the Convention on Biological Diversity). 2008. Protected Areas in Today's World: Their Values and Benefits for the Welfare of the Planet. Montreal, CBD Technical Series 36, 96 p.

Silva, F.A.B., Costa, C.M.Q., Moura, R.C. \& Farias, A.I. 2010. Study of the dung beetle (Coleoptera: Scarabaeidae) community at two sites: Atlantic Forest and clear-cut, Pernambuco, Brazil. Environmental Entomology 39: 359-367.
Silva, P.G. 2011. Dung beetles (Coleoptera: Scarabaeidae: Scarabaeinae) of two non-native habitats in Bagé, Rio Grande do Sul, Brazil. Zoological Studies 50: $546-559$.

Solís, A. \& Kohlmann, B. 2002. El género Canthon (Coleoptera: Scarabaeidae) en Costa Rica. Giornale Italiano di Entomologia 10: 168.

Spector, S. \& Ayzama, S. 2003. Rapid turnover and edge effects in dung beetle assemblages (Scarabaeidae) at a Bolivian Neotropical forestsavanna ecotone. Biotropica 35: 394-404.

Stone, T.A. \& Lefebvre, P. 1998. Using multi-temporal satellite data to evaluate selective logging in Para, Brazil. International Journal of Remote Sensing 19: 2517-2526.

Tabarelli, M., Melo, M.D.V.C. \& Lira, O.C. 2006. A Mata Atlântica do Nordeste, p. 149-164. In: Campanili, M. \& Prochnow, M. (eds.). Mata Atlântica - Uma Rede pela Floresta. Brasília, Rede de Ongs da Mata Atlântica, 332 p.

Received 4 February 2013; accepted 13 August 2013

Associate Editor: Rodrigo F. Krüger 